\title{
Article
}

\section{A Contemplative Approach to Graduate Writing Development: Reflections from Thai Writing Classrooms}

James Burford 1

Faculty of Learning Sciences and Education, Thammasat University

Adisorn Juntrasook

Faculty of Learning Sciences and Education, Thammasat University

Wasana Sriprachya-anunt

Faculty of Learning Sciences and Education, Thammasat University

Linda Yeh

Faculty of Learning Sciences and Education, Thammasat University

\section{Abstract}

This article addresses an under-researched area of writing studies: the use of contemplative pedagogies in the development of graduate writing. Drawing on reflective analysis from writing instructors, this article seeks to both contextualize the teaching and learning of writing in the Thai context, and to introduce experiments in contemplative writing pedagogy. In particular, the article reports on graduate-level writing courses that are embedded within the curricula of two educationfield Masters programmes in Thailand. Four instructors involved in these courses reflect on their combined experience of integrating contemplative pedagogies, describing the steps they undertook to bring these into the classroom. The contribution of this study is its reporting on research in the under-considered area of contemplative practices, as well as opening up the consideration for graduate writing development in non-Anglophone contexts, such as Thailand. It is hoped that the documentation of the tools and strategies used by Thai instructors will assist others to bring contemplative approaches into play in their own classrooms. 
Volume 28, 2018

http://journals.sfu.ca/cjsdw

\section{Introduction: Graduate Writing as an International Object of Concern}

Writing has so much to give, so much to teach, so many surprises.

-Ann Lamott (1995, p. xxvi)

The ability to write fluently has long been regarded as a vital aspect of graduate becoming. Writing is a desirable professional capacity that assists students entering employment markets, as well as a means by which disciplinary knowledge is itself learned and communicated. Yet a suite of changes to universities over recent years has seen graduate writing crystalize as an object of concern. Growing international anxiety about the state of writing emerges in a time where the meanings attributed to graduate study are undergoing profound transformation. Increasingly, policymakers have identified graduate education as an important tool for national success in a global knowledge economy (Lillis \& Scott, 2007; Tennant, McMullen \& Kaczynski, 2010). Graduate students have become recast as "advanced knowledge workers" (Lee \& Boud, 2009, p. 18), and their attrition rates, times to submission and writing productivity have all been tied to broader concerns about the economic competitiveness of the nation. Writing, in particular, has become understood as a key component of innovation via higher degree research, as well as a transferable research capability that future knowledge workers should be equipped with (Wellington et al., 2005).

The changing cultural meaning of graduate education and the increasing diversity of graduate student cohorts has led governments and institutions to identify writing "as a key location for the collapse of high-level scholarly achievement" (Lee \& Aitchison, 2009, p. 93). As a result, there have been increasing efforts to manage the so-called writing problem (Bansel, 2011; Burford, 2015, 2017a, 2017b; Cuthbert \& Spark, 2008; White, 2015). Across institutions there has been increasing regulation of writing, and students and supervisors are more intensively surveilled with regard to the quality, quantity, and timeliness of written outputs (Blackmore, 2009; Cribb \& Gewirtz, 2006). Despite growing concern about graduate writing, as Paré (2017) writes from the Canadian context, this has not necessarily resulted in significant investments in institutional support. While Susan Miller (1991) used the phrase "sad women in the basement" to evoke the marginal place of writing instructors in universities in the United States, recent accounts have documented the ongoing challenges that North American writing centres face regarding their "existence, funding and stature" (Bromley, 2017, p. 24). 
Volume 28, 2018

http://journals.sfu.ca/cjsdw

The context for graduate writing instruction in Thailand shares both similarities and differences to accounts emerging from North America. Since the 1997 Asian Monetary crisis, and ensuing 'rescue packages' of the World Bank and International Monetary Fund, Thailand's higher education sector has also become increasingly neoliberal (Lao, 2015). However, unlike in the Global North, in Thailand there has been scant scholarly attention given to graduate student writing development. This absence is curious, especially given increasing institutional pressure for timely completion and scholarly publication as a degree confirmation requirement. In Thailand, and some other institutions in Asia (see Li, 2015), postgraduate students may be required to publish one or more first-authored, peer-reviewed articles to complete their studies. This can leave students in years of limbo as they wait for articles to be published, even when their thesis itself has been examined. Arguably, the motivations of Thai institutions to increase graduate writing output are not purely educational. In a competitive higher education environment, Thai universities rely on the scholarly outputs of their graduate students to bring prestige and lift their rankings on domestic and international university league tables.

In recognition of their desire to increase student publishing, Thai institutions have not typically invested in a model of support and mentoring. At our institution, for example, there are currently no central writing workshops, drop-in support, or formal mentoring programs offered. Occasionally, individual faculties may hire English-speaking staff to assist with the proof-reading of abstracts or articles, but this does not appear to be commonplace. Instead, the preferred approach appears to be a combination of regulation (making publishing a graduation requirement) as well as financial incentive. For example, graduate students are offered a 'bonus' for publishing work to a certain (metricizable) standard. Indeed, this is true, not only for graduate students but also faculty members, whose publication bonuses per article can far exceed an academic's monthly base salary. It is our view that Thai graduate students and their instructors are under pressure to intensify their writing output, but have not been given much support to meet these expectations. Within Thai institutions we discern a focus on writing products and productivity, but limited investment in formal teaching and learning about writing. As instructors of graduate students, we are interested in exploring how we can think differently about writing instruction. We want to understand how we can both prepare our students for the academic expectations they will encounter, as well as identifying possibilities for writing that exceed reductive and technicist rationalities (Bansel, 2011).

This article reports on attempts to embed writing and use contemplative pedagogies within two graduate programs in Thailand. We position the embedding of writing within disciplinary curricula 
Volume 28, 2018

http://journals.sfu.ca/cjsdw

as an important response to absences of institutional support, and understand our turn to contemplative pedagogies to be an innovative teaching approach with the potential to exceed narrow, product-oriented approaches to graduate writing. Contemplative pedagogies are innovative in our teaching context as they enable a focus on learning as not only a goal, but also a pathway (Grace, 2011). The intention behind contemplative pedagogies is to cultivate "inner awareness through firstperson investigations, often called 'contemplative practices'” (p. 99), which may include "silent sitting meditation, compassion practices, walking meditation, deep listening, mindfulness, yoga, calligraphy, chant, guided meditations, nature observation, self-inquiry" (Grace, 2011, p. 99) and many more.

We understand that there may be some curiosity as to why a group of Thai-based writing instructors have chosen to share such a reflection with the Canadian community of writing scholars. Our response is quite simple; we believe that contemplative concepts have the capacity to travel across international borders. Indeed, there has been a recent flowering of such approaches in North American universities (Barbezat \& Bush, 2014; Davis, 2004; Jones, 2016; Wenger, 2015) and we hope that our own offering might stimulate further interest among writing scholars in particular. More broadly, we hope that sharing graduate writing classroom contexts that may be unfamiliar to Canadian colleagues offers productive opportunities for comparison and contrast-an invitation to reflect on what may be taken-for-granted or assumed to be common sense.

The remainder of this article is organized as follows: in the next section, we offer an account of the particular problems regarding graduate writing development that arise in the Thai higher education context, and offer our characterization of the existing Thai literature on the teaching and learning of academic writing; the second section of the paper introduces our conceptual framework and extends existing studies which have begun to describe a contemplative approach to academic writing pedagogy (Barbezat \& Bush 2014; Simmer-Brown, 2016); in the third section, we share detailed examples from our own pedagogical practice as points of reflection for other instructors to learn alongside us; finally, we discuss the implications of our study and outline opportunities for further research.

\section{Learning to Write in Thailand: A Space, an Absence}

As we outlined above, the purpose of this article is to describe the contemplative pedagogies we have used as lecturers who offer writing courses in Thailand. We acknowledge that writing is a contextual practice that needs to be grounded in the particulars of time, place, and space (Reynolds, 2004). As such, it is important to situate this discussion in the context of writing instruction in Thailand, which 
Volume 28, 2018

http://journals.sfu.ca/cjsdw

does have significant differences when compared to North America. For example, while in the Canadian context there have been active debates about the status of institutional writing support and research (Paré, 2017), even basic units, such as writing centres, are missing from Thai universities.

In this section, we pause to map what has been written to date about the Thai context for teaching graduate writing. This is particularly challenging given the limited range of Thai writing studies to date, published in either the English or Thai languages (for exceptions see: Chaisiri, 2011; Sorapat, 2014; Tangkiengsirisin, 2011). For example, in preparation for this article we examined theses and dissertations published between 2005 and 2015 on the National Research Council of Thailand (NRCT) online database, and found that there were no studies conducted on the teaching of graduate writing. Only 14 out of 184 studies on the teaching of writing were conducted with college students, whereas nearly two-thirds of the studies focused on the elementary and secondary levels.

Among the few studies we have located on teaching graduate writing in Thailand, researchers tend to focus on instructional interventions to improve students' academic writing skills, such as written feedback on the organization and coherence of students' writing (Tangkiengsirisin, 2011). Other studies have emphasized the challenges students tend to face, including Sorapat's (2014) investigation of graduate linguistics students' and instructors' perceptions of difficulties in academic writing. Sorapat (2014) found that the majority of the students in her study struggled to make sense of and apply the theories they learned to the assigned writing topics, that they had difficulties in paraphrasing and utilizing the appropriate vocabulary, and had limited knowledge of writing processes. The majority of the instructors in the study felt that students did not have sufficient knowledge due to a lack of reading, and difficulty in synthesizing new knowledge from the reading they undertook. Furthermore, the key writing skills that students struggled with were around cohesion and coherence, a finding noted by other researchers (Chaisiri, 2011; Tangkiengsirisin, 2011). It is our view that this slender body of research does not yet provide a comprehensive enough picture of graduate writing development in Thailand, and we hope to contribute to this space.

If we want to understand graduate writing in a holistic way a helpful place to begin is by looking at Thailand's Basic Education Curriculum². A closer examination of this document reveals that literacy in the Thai language is identified as a critical skill for both learning and cultural identity. The most recent national curriculum is divided into eight learning areas, including one area focused on the Thai language (Bureau of Academic Affairs and Educational Standards, 2001). In the sub-area of writing, students in Matthayom 4 to 6 (equivalent to grade 10 to 12) are expected to be able to communicate using various formats such as synopses, narratives and stories, reports, study notes, 
essays, and academic research. Additionally, students are expected to use writing skills for selfdevelopment, evaluate writing pieces to improve their own writing, and exercise writing etiquette (Bureau of Academic Affairs and Educational Standards, 2001).

While learning to write does have an explicit place in the Thai basic education curriculum, often it is taught in an implicit way. Schools have the freedom to create their own syllabi, and teachers are entitled to design lessons with their own focus. Our overall impression from our discussion with secondary teachers is that there tends to be limited emphasis on writing in comparison to other literacy skills. Teachers have told us that format, style, and the surface level of composition tend to be given the most time, sometimes in the form of dictation exercises. In many cases, it seems, writing instruction is product-oriented, involves a simple and static structure (e.g. introduction, body, conclusion) and critical thinking about plagiarism is not highlighted.

We can see several contributing factors to the limited emphasis on writing in schools in Thailand. One of these is that composition is not assessed in the Ordinary National Education Test (O-NET), which is compulsory for Thai students in grades 3, 6 and 12 and is used to determine university admissions. The Thai language examination is mostly focused on demonstrating grammatical knowledge and reading comprehension rather than writing ability via a composition test, for example. With no external assessment of the writing development of Thai secondary students it is perhaps unsurprising that writing has taken a backseat role. As a result, many of our Thai students encounter challenges in producing writing that meets academic expectations when they enter universities.

Once students arrive to Thai universities, writing instruction remains limited. At our institution, for example, a compulsory general education subject called "Critical Thinking, Reading, and Writing" is offered for all freshmen. This is a one-semester course mostly taught by academics in the Faculty of Arts. Beyond this subject, students may have little formal instruction with regard to academic literacies in their discipline. As we mentioned above, no general support is offered across the institution. At the graduate level, the generic regulations at Thai universities for the production of theses and dissertations are strict, and research students are often given a standard structure that with which they are expected to comply. This usually involves a five-chapter thesis (i.e. introduction, literature review, methodology, results/discussion, and conclusion). Because of the fixed nature of the shape and style of theses, many students are advised to follow the patterns and writing style used by graduate students before them. The graduate schools of some universities offer a thesis template, 
Volume 28, 2018

http://journals.sfu.ca/cjsdw

which outlines the expected components of the thesis. Other graduate schools go further, offering to format the student's thesis in exchange for a fee.

Another feature we have noticed in our experience of teaching in Thai universities is a pattern of writing that is colloquially called "kanom chan" (the name of a Thai layer cake). This pattern of writing arises when students conduct literature reviews for their assignments or theses/dissertations, and report the literature in a "he says, she says" manner with limited synthesis ${ }^{3}$. This writing pattern is so common that when we have brought examples of different literature reviews into our classrooms many of our students immediately identify the "kanom chan" example as the 'correct' format for conducting a review. While there has been no research on the emergence of this pattern of writing in the Thai context, we have located several educational research methodology and thesis writing guidebooks written by academics that suggest this is the proper pattern for doing literature reviews. We have also located some online materials such as teaching slides (i.e. Teerakul, n.d.; Thaotrakool, 2016) and speakers from the National Research Council of Thailand (i.e. Meekun, 2009; Phuangpornpitak, n.d.) and a faculty blog (Suriya, n.d.) that advise against a "kanom chan" style of writing.

It is our view that the conventions that surround graduate writing in Thailand-absences of instruction, fixed thesis structures, and reproducing "kanom chan" styles of reporting literaturesare often constraining for our students. We believe that they do not enable the kind of flexibility and creativity from which good graduate work benefits. While there are clearly further gaps in our characterization of writing development in the Thai context we hope we have provided an initial platform for others to build on. In the next section we introduce the conceptual basis of our article, contemplative pedagogies, and explore how they have been applied to the teaching of academic writing in previous studies.

\section{Introducing Contemplation as an Approach to Teaching Graduate Writing}

In order to respond to the teaching and learning challenges that we identified above, we began to search for pedagogies that were less product-oriented and more process-focused. In particular, we wished to identify approaches to teaching and learning that could address students' writing confidence at the same time as responding to their personal and professional development. Some authors of this article have been involved in movements to develop contemplative approaches to 
Volume 28, 2018

http://journals.sfu.ca/cjsdw

higher education in Thailand, and saw this as a possible way forward. Within Thailand, contemplative education approaches have become identified as possible routes to revitalize humanistic values in education in the face of creeping capitalism and commercialism (Vasi, 2007). Even though the foundation of contemplative practices may connect to Buddhism, which has a long history in Thailand ${ }^{4}$, it also draws on other forms of Eastern and indigenous wisdom.

Contemplative practices are not only increasingly popular in Thailand, they are an international phenomenon that have spread across the field of higher education in the last decade (Barbezat \& Bush, 2014; Morgan, 2015; Shapiro, Brown \& Astin, 2011). Indeed, in a recent article Arthur Zajonc (2013) describes contemplative pedagogy as higher education's "quiet revolution." The term 'contemplation' derives from the Latin contemplari which means to "gaze attentively," but as Barbezat and Bush (2014) note, the word was historically linked to the act of "cutting out or creating a space" for observation (p. 21). In its contemporary form, contemplative education is based upon two principles: humanistic value and the holistic paradigm. Humanistic value is the belief that all human beings have the potential to learn and develop themselves, while the holistic paradigm emphasizes interdependence among humans, other beings, and surrounding environments. In practice, contemplative education can be understood as a process of learning that focuses on developing self-awareness, deep understanding and compassion towards oneself and others through meditation, mindfulness, and other introspective practices (Nilchaikovit \& Juntrasook, 2016). Pedagogies informed by contemplative approaches focus on personal reflection and integration in the learning encounter, and offer conceptual resources that exceed rationalist and cognocentric world views (Morgan, 2015). As teachers, contemplative educators aim to teach the "whole person, with an intention to go beyond the mere transfer of facts and theories" (Barbezat \& Bush, 2014, p. 3). While some contemplative practices have emerged from spiritual models such as theological reflection (Killen \& DeBeer, 1994), others have been integrated into secular educational contexts such as schools (Bryant, 2012), and universities (Wenger, 2015). The increasing trendiness of contemplation in the field of education has not only been motivated by efforts toward a more socially just and caring society, it is also driven by research that suggests benefits for university teaching, learning, and scholarship (Barbezat \& Bush, 2014). For example, evidence suggests that contemplative approaches have positive effects on students' metacognitive development, effective communication, deep learning and critical reflection of the subject studied, and inner growth (Borker, 2013; Morgan, 2012; Nuangchalerm \& Prachagool, 2010). 
There has been growing interest in applying contemplative principles to the teaching and learning of student writing, as evidenced by recent calls for papers in scholarly journals (Miller \& Bhattacharya, 2017), the formation of special interest groups (NCTE, 2017), and the growing number of published books, blog posts, and articles (Barbezat \& Bush, 2014; Burton, 2016; Davis, 2004; Jones, 2016; Simmer-Brown, 2016; Wenger, 2015). This interest had been taken up in popular books on writing such as Anne Lamott's (1995) Bird by Bird and Natalie Goldberg's Writing Down the Bones which both engage its spiritual dimensions. For example, Lamott (1995) advises that writing can be conceived of as a way of attending to, and being present in, the world-a way of calming our 'strobostropic' minds (1995, p. xiv). She also notes many things that contemplative educators might be interested in, for example, the steadying impact of deep and slow breathing (p. 17). Goldberg (1986) draws on Zen Buddhist philosophies to invite readers to approach writing as a quotidian meditative practice.

Thinking about contemplative approaches to writing has also surfaced in scholarly texts. For example, in their book Contemplative Practices in Higher Education, Barbezat and Bush (2014) offer a chapter on contemplative approaches to reading and writing (pp. 110-136). As the authors note, reading and writing have long been considered to have sacred roots, such as the Christian tradition of lectio divina (contemplative reading). Today, writing assignments are recognized as one of the most important ways that student learning is integrated. Barbezat and Bush (2014) argue that contemplative practices can be helpful conduits to "deepening students' understanding and stimulating their insight and creativity" (p. 110). It is their argument that the practice of writing is enhanced by the capacities that mindfulness and other contemplative practices develop. Often contemplative approaches to writing emphasize process over outcome, for example in free writing students are encouraged to explore a practice of:

noticing what is in the mind and in the world and writing the raw truth as experienced, not crafted for communication until later...the truth is often revealed in the quickness, in not judging, in the safety of knowing no one will read it unless you want them to. The reflection, the editing, comes after the exercise. (p. 124)

Other approaches surveyed Barbezat and Bush (2014) include journal writing, free writing, writing about reading, mindful writing, and storytelling. These pedagogical approaches are used to 
Volume 28, 2018

http://journals.sfu.ca/cjsdw

encourage students to not only reflect on the content of their materials but also to inquire into their own inner life and identity and how this may relate to their class-based learning.

Various books on writing development align themselves with a contemplative approach. For example, in his book The Journey from the Center to the Page (2004), Jeff Davis argues that the philosophical principles and tools of yoga can help creative writers enrich their writing practice. He argues that "our breath and body...can in part be the muses that help us learn to navigate our fluttering minds, our tricky imagination, and our unpredictable hearts as we write (and rewrite)" (p. ix). This interest in yoga and writing as an embodied-contemplative practice has been echoed by Christy Wenger in her book Yoga minds, writing body: Contemplative writing pedagogy (2015). Wenger argues that writing and yoga are linked by a "common core of mindfulness" (p. 3), and outlines how she introduced Iyengar yoga practice in her first year composition class under the frame of "yoga for writers" (p. 4). Wenger's use of yoga in her composition class emerges out of a view that the body is "a lived site of knowledge and not, primarily ...a discursive text" (p. 10). She notes that her goal is to "bring the body into the domain of the writing classroom, hopefully teaching students to think about their bodies as generators of meaning" (p. 23). Indeed, Wenger's work aims to reimagine the writing subject as a "body-heart-mind" (p. 25). Other scholars, such as Jones (2016) have also written about leading contemplative writing courses, and the need to create spaces of "solitude and focus" (p. 67) for writing students. Taken together, these texts demonstrate that contemplative pedagogies present interesting possibilities for use in the writing classroom. In the next section we explore the how contemplative practice informed pedagogical practice in our own Thai writing classrooms.

\section{Reflections on Practice in two Thai Universities}

In what follows we introduce the motivations behind the two courses investigated in this article (at Mahidol University in 2014, and Thammasat University in 2015-2017). In line with Haggis (2006), our goal in establishing these writing classes was to move away from an "individualised focus on needs, deficits and 'support" toward a view of the "barriers to learning" our students encountered (p. 521), and the possibilities writing might offer for their own growth as scholars and people. Rather than trying to "fix" the learning issues of our students, we tried to take the perspective that we, as instructors, needed to take more responsibility for the teaching of writing. As Haggis notes, this shift meant that the central pedagogical question changed from "what is wrong with this student" to "what are the features of the curriculum, or of processes of interaction around the curriculum, which are 
Volume 28, 2018

http://journals.sfu.ca/cjsdw

preventing some students from being able to access this subject?" (p. 526). We found that contemplative pedagogies offered us some helpful tools to use because they not only avoid the notion of individual student deficit, but also offer a new understanding of learning as a pathway, rather than a product. This new understanding enables students to approach their writing development in a more holistic way where their full potential as both a scholar and a human being can be attended to.

Before we introduce the activities we used, it may be useful to note that our decision to include writing instruction in our formal curriculum is unusual. As Helen Sword (2017) illustrates, offering a formal context for the learning of writing is rather rare internationally. In Sword's (2017) study of over 1,300 academic writers, most respondents (47 percent) reported that they learned to write informally. More than one third (38 percent) had some semi-formal training (such as reading advice texts, or attending occasional workshops). Only fifteen percent of Sword's sample had been offered formal academic courses on writing. By courses she means a formal learning program that is iterative, cohort based, expert facilitated, research-informed, draws on learning activities, and is certified at the end. All of these components are reflected in the courses we offered in Thailand.

Our goal in the following sections is to demonstrate some of the contemplative pedagogies we have used to help graduate students think about and develop their writing. For the purposes of writing this article, we have selected six activities we conducted in classes which we taught across the two different institutions based in the wider Bangkok metropolitan area. We view these activities as contemplative in the sense that they offer opportunities for self-inquiry and reflection; they may be used in different contexts as warm-up exercises or as substantive classroom activities. While some contemplative pedagogies such as meditation, deep listening, mindfulness, and self-inquiry are starting to emerge in Thai higher education, the activities that we illustrate below have, to our knowledge, not been applied to the instruction of graduate writing in this context previously. Equally, most of them would have been novel experiences for our students. While in other contexts some of these activities may not be recognized as 'contemplative,' in this article we recognize them as such, because our intention in practicing them is to develop our students' potential in a holistic way.

\section{Case one: A contemplative writing class for graduate students at Mahidol} University

Adisorn Juntrasook (AJ) taught a group of Masters of Arts (Contemplative Education) students at Mahidol University, Thailand. This elective course was scheduled after students had finished their other required courses and were in the process of writing their thesis proposals. In addition to the 
Volume 28, 2018

http://journals.sfu.ca/cjsdw

students who enrolled in the class, a number of other students who had finished their coursework also attended. In the "Contemplative Writing" course AJ aimed to assist students to build confidence as they approached their research writing process. As he had already met this group of students before, AJ understood that many of them were concerned about their writing abilities. Most of the students he had spoken to said they had a very difficult relationship with writing. Many students reported they did not know what to do or how to start, that they feared being judged on the basis of their writing, and that they felt unsure how to overcome their writing blocks. Instead of choosing to focus on technical knowledge (e.g. how to write a thesis proposal), AJ decided to design this class as an experimental lab for his students to explore some positive feelings towards writing. One of his hopes was that students might open up new ways of thinking and practicing writing in a way that was congruent with their own learning journeys. He hoped that their experience of writing in his class might help them become more confident about their own research writing as well.

Here, AJ will reflect on three activities he used in this contemplative writing class:

Intuitive writing. Many educators use free writing techniques to assist students to "observe their emotional, intuitive, or physical responses to course material” (Barbezat \& Bush, 2014, p. 133). As Barbezat and Bush (2014) argue, "it is a method of inner inquiry: you never know what you will learn until you start writing" (p. 133). The activity I conducted began with each student sitting down with a piece of blank paper and a pen or a pencil. I asked students to start writing whatever arose in their mind for a period of six minutes without stopping (i.e. the pen or pencil should always be in motion). Students were told that even if they did not know what to write they should keep writing whatever came to mind, for example "I don't know what to write, I'm confused what to write, what should I write?" I advised students that they could write sentences, words, phrases, or draw images. The purpose of the activity was for students to let go of their own judgments (and fears of being judged by others), which often stopped them from beginning their writing. Focusing on the task of writing without stopping allowed students to write without having to consider what was or was not appropriate or whether they were using correct spelling or punctuation. This activity was a good warm up activity, not only because it allowed students to start writing right away, but also because it allowed students to get what was inside their head (what they might be worried about) into a container (paper or screen) which could help them to move on to their actual task. In this sense, free writing can "free the writer" (Barbezat \& Bush, 2014, p. 133). From my observations of the classroom I noticed that many students enjoyed the practice of intuitive writing because it offered an opportunity to calm the mind, and develop clarity about what they wanted to say in their writing. 
Volume 28, 2018

http://journals.sfu.ca/cjsdw

Letter to a significant other. This activity was used once in my classroom. It was inspired by Ann Lamott's (1994) letter writing activity in the book Bird by Bird: Some Instructions on Writing and Life. According to Lamott, when writers "really don't know what else to do, when you're really stuck with despair and self-loathing and boredom" (p. 172), writing a letter can be a helpful way forward. Lamott suggests that the informality of the form of the letter might free writers from the "tyranny of perfectionism" (p. 172).

In my classroom I asked students to spend ten to fifteen minutes writing a personal letter about a topic they chose in their assignment or research proposal to a significant other (a family member, friend, etc.). Students were asked to explain their research, why it is important to them personally and academically, what they are trying to achieve in writing about the topic, what their hopes and fears are in writing it, and whatever else they wanted to express to that particular person. The purpose of writing this kind of letter was to invite students to reflect on and communicate about their chosen topic in a holistic way. This activity seemed to help students to recognize the feelings attached to the topic that prevented them from starting to write.

After writing their letters I invited students to spend about five minutes reading through their work and to reflect on what they could learn from this letter. Then students were asked to get into pairs to share what they learned from this writing activity, and then to share these discussions with the wider class. When asked what was useful about this activity, students shared that often they found their professional and personal identities were fragmented, and that this activity offered opportunities to integrate these two important aspects of their lives. Moreover, the activity allowed students to anchor the purpose of their research projects, as this often became lost.

News headlines and stories. I began this activity by inviting students to close their eyes. Once all of the students were still, I guided them through a series of questions which asked them to reflect on their research projects as an experience and story. Students were asked to visualize their research experiences in a concrete way with questions such as: What have you done so far in your research?; Who did you talk to?; How did you collect data?; What responses did you get from your informants?; What did the informants look like when they met you?; How do you plan to analyse your data?; Where do you plan to do it?; and, What will be the end result of your study? After this process of reflection, I asked students to open their eyes and imagine that they were going to turn their research experience into a news story. Students were invited to imagine the predicted results of their research as if it were featured in a newspaper, and spend 10 to 15 minutes writing, making sure to include a short headline that demonstrated the most significant contribution of their research. After students 
Volume 28, 2018

http://journals.sfu.ca/cjsdw

finished writing their short articles they were asked to swap them with a peer and read one another's work. I asked students to give their classmates feedback on whether the headline captured the essence of the story, and to comment on the flow and structure of the story. In class, students were asked to revise their story after listening to the feedback of their peer, a process that continued until both parties were satisfied with the revisions. In total the activity lasted around 45 minutes.

The purpose of this activity was to help students to contemplate the journey of their own research project from beginning to the end, and also its contribution to society and the academic community. This is important because often students feel isolated and lost, and lose confidence in the worth of their research project. This feeling then often affects their self-confidence. On a practical level, this activity allowed students to see their project from a third-person perspective, and assisted them to find ways of communicating it to the public in accessible language. Focusing on the task of writing very short news headlines and stories helped the students to articulate their work more succinctly. Additionally, the activity sharpened their storytelling and presentational skills, which is helpful beyond just writing, but also for both their thesis and their wider professional contexts. Students reported that they were surprised to recognize the value of their research, which they often had doubts about while in the middle of the project.

\section{Case two: Contemplative approaches to graduate writing development at Thammasat University}

The class we, James Burford, Linda Yeh, and Wasana Sriprachya-anunt, are reporting on is a master's level course called "Critical Reading and Writing" which was delivered at Thammasat University, Thailand. The course was first developed in 2015, and has been delivered in both Thai and English simultaneously over three cohorts of students (2015-2017). The course was a non-credit compulsory course (pass/fail), in the first semester of a Master of Education in Learning Sciences and Educational Innovation, which is intended to take students around two years to complete. The course was developed and taught by three teams, who came from varied disciplinary backgrounds. The group of students also came from diverse backgrounds and educational experiences, and the purpose of the course was to help students adjust to reading and writing at the graduate level. An additional goal of our teaching was to address common (mis)understandings about graduate writing, such as the emphasis on a very strict and inflexible five-chapter thesis structure, or the preference for "kanom chan" style of literature reporting. In our classrooms we tried to develop a more open field of possibilities, where students could revisit taken-for-granted notions of what writing is and does. 
Volume 28, 2018

http://journals.sfu.ca/cjsdw

Here, the teaching team of Burford, Yeh, and Sriprachya-anunt will reflect on three contemplative activities they used in their critical reading and writing class.

Creative approaches to reflecting on writer identity. In the first session of our writing class we conducted an activity which asked students to explore their identities as writers. We uploaded a slide which had pictures of various people writing in various places (from a desk, to a bathtub, to relaxing on a couch). We provided materials to students including pieces of blank paper, felt tip pens and pastels. To begin the activity, we asked students to take a moment to reflect on their own experiences with writing, their own sense of themselves as writers and the feelings that arose when they thought about writing. We then gave the students around 20 minutes to complete their drawings. Once the students created their artifacts we asked them to pair up with their neighbors and to discuss the content of the pictures and the meanings that might be found in them. Following some pair discussion, we asked for volunteers to share their drawings and stories with the whole class.

Our purpose with this activity was to ask students to reflect on themselves as be(com)ing writers. We wanted to use pictures as a tool to allow students to be playful and creative. Another goal in asking students to draw pictures of themselves as writers was to emphasize to students the skills and abilities that they already possessed. All too often students come to class with narratives that they were not good writers. Our goal was to show that as students who entered graduate programs they were already writers, whether or not this was an identity that they took on for themselves, or with which they were particularly confident. In so doing, we wanted to emphasize their strengths rather than their deficits. This activity also provided an opportunity for students to come to know themselves and their classmates better, and we as instructors got to know our students and to learn about their pleasures, pains, and insecurities around writing. In reflecting on this activity later, we recognized that the pictures that students drew often had a host of negative feelings such as insecurity, fear, and lack of confidence. Holding this activity at the beginning of our class seemed to help to get these feelings out in the open in order to begin in an authentic place where we become vulnerable with each other and our learning needs.

Scrapbooking. Journal writing has long been identified as a helpful method of self-exploration (Barbezat \& Bush, 2014). One of the assignments given to students was a particular form of journaling-a scrapbook of reading students had completed over the course of their study, and reflections on these texts. We asked students to locate newspaper articles, blogs or other kinds of media that they encountered in their daily and professional lives, to reflect on how they, as readers, responded to them. This activity was our attempt to encourage students to find themselves in what it 
Volume 28, 2018

http://journals.sfu.ca/cjsdw

is they are studying (Barbezat \& Bush, 2014, p. 6). Our use of this activity builds on existing examples, such as Janet Berlo's work in her course "Art and contemplative Practice" at the University of Rochester (cited in Barbezat \& Bush, 2014, pp. 130-131). Berlo asks students to create a journal based on reflections/responses to class discussions, she also requests students to engage the intellectual and affective dimensions of the discussion and hopes her students "will also insert other items that you happen upon in your quest: items clipped from magazines or newspapers, visual images that please you, photocopied quotes from diverse sources" (Berlo, n.d., cited in Barbezat \& Bush, 2014, p. 131).

In our case, students were asked to make at least 10 entries in their scrapbook over the course of the semester, and instructors made demonstration scrapbooks to show the students what might be possible with the assignment. We asked students to submit two entries initially, and then they were given formative feedback. The third to tenth entries were done without feedback until the end of the semester in order to give students time, space, and privacy to create. Students were encouraged to use arts materials and decorate their scrapbook in a way that appealed to them.

Most of the students shared their opinions about the media that they engaged with, often taking these pieces of writing and relating it to their professional contexts. We did not ask students to write about what they learned in their classes per se, but invited them to use what they learned at university as a lens on the cultural texts that they found in their own environments; this was valuable because it allowed students to ask critical questions about educational practices and policies. Many students focused their attention on the creative aspects of the scrapbook, and have remarked that they used some of the reflective skills they developed in this activity in their thesis reading and writing. It was also clear that not everyone found it natural or easy to scrapbook frequently, so there were some inconsistencies in the amount of effort students put into the project. In future applications of this activity, practitioners could think about periodically reading the work of the students to give formative feedback and/or to have a one-to-one consultation with students about any blocks that may arise. Another helpful possibility could have been to involve peers in the feedback process.

Freewriting. As per the Mahidol case above, free writing was taught as a part of a process-based approach to composition. We taught students to use freewriting as a part of their 'pre-writing' process including other tools such as brainstorming, mind mapping, and outlining. However, we aimed to conduct freewriting in a contemplative manner, often using it as a warm up activity, sometimes combining it with a practice of silent meditation or morning stretches. Our goal in offering this activity was to create a "spacious moment" (O'Reilley, 1998, p. 6) at the beginning of class. Our 
Volume 28, 2018

http://journals.sfu.ca/cjsdw

instructions for freewriting tended to be as follows: we began by giving our students a piece of paper and a pen and then ask students to keep writing (moving their hands and writing nonsense if necessary) until we rang a bell (which was their signal to stop writing); after the freewriting we asked students to spend some time reading over their text, and to circle any words or phrases that they might find useful for their thinking about their current project. We emphasized to students that their freewriting was private, they did not need to share it with anyone if they did not want to; after the free writing exercise we solicited reflections from students in class who shared their experiences during the activity. Instructors also participated in the activity to demonstrate to students that this was a practice from which all writers can benefit.

\section{Discussion and Conclusion}

Our present investigation has been an attempt to extend considerations of the possibilities of contemplative practice for the teaching and learning of writing (Barbezat \& Bush, 2014; Burton, 2016; Davis, 2004; Simmer-Brown, 2016; Wenger, 2015), as well as addressing gaps in the existing research about graduate student writing development in the context of Thailand. We have approached this article as teacher-researchers hoping to share what we have learned as a result of our own practice. As we have outlined in this paper, in Thailand the explicit teaching of writing does not have a strong institutional presence, as either an object of pedagogy or research. Our work in the area of graduate writing pedagogies was prompted by a desire to help our students develop their academic literacies, and to do so in a way that was open to the wider possibilities that learning about writing could offer.

The contemplative pedagogies we have outlined in this article do not necessarily seek to assist students to complete a particular research project, and are not oriented to writing quality or productivity per se. Instead, our goal in enacting these pedagogies is to enable students to become more reflective, and hopefully also feel more positive and confident about themselves as writers. This is, we argue, what contemplative pedagogies bring to debates about innovation and graduate writing development. We have been happy to observe some of our students making shifts in their attitudes toward writing. Some of the most important progress our students have made is in their willingness to begin composing without fears of judgment-feelings that often used to hinder them. A number of students also reported to us that they found themselves enjoying some of the experiments we organized, which encouraged them to use some of these practices (such as freewriting) in their own research writing practice. Contemplative approaches to writing also helped our students to become 
more reflective on problems they may encounter on their writing journeys. Even though some of these problems may commonly be described as 'personal', or 'psychological' these pedagogies gave students space to address them.

It is important to emphasize here that the contemplative pedagogies we have shared here are not necessarily oriented to producing 'better' writers. Instead, this approach understands that students arrive in class with multiple identities, they are never just a graduate student, a writer, or an advisee. Our approach views students more holistically, as human beings whose capacities to write may be developed alongside other human qualities. As we see it, not only seeking to create 'better' writers is part of the value of contemplative pedagogies. By creating less judgmental and competitive learning environments we place more emphasis on nurturing individual development rather than 'excellence.' This is an effective response to deficit framings of the student which tend to have a very fixed notion of what 'success' looks like (Burford, 2017b). Indeed, it is our hope that such a focus on the process of learning, and the provision of tools to manage its affective dimensions, will be helpful for our students as they encounter stress and anxiety across their graduate learning experience.

Our discussion of contemplative pedagogies in this article has detailed the growing popularity of such approaches. It would be insufficient, however, to regard such approaches as the solution for the challenges that students face in learning how to write. There are, of course, challenges with contemplative pedagogies that need to be further explored and theorized. Notwithstanding these issues, we argue that contemplative pedagogies have the capacity to address the importance between the self as a learner and communication through writing. We have shared a set of examples for contemplative practice that are available for other teachers to use in order to expand the possibilities for graduate writing development. While our experience is located within Thai writing classrooms, we hope that these pedagogies have wider application given the shared stresses that many graduate writers face. As we are members of a relatively new faculty (established in 2014), we have had the opportunity to be imaginative in teaching and learning with our students. We have already expanded our use of contemplative writing pedagogies beyond the area of writing development itself, adapting some of the learning activities discussed in this article to other curriculum areas. We hope to continue exploring the potential of contemplative practices to unite both personal and professional growth.

\section{Endnotes}

1. Correspondence may be addressed to jburford@tu.ac.th 
Volume 28, 2018

http://journals.sfu.ca/cjsdw

2. The Basic Education Curriculum serves as core curriculum for national education from Prathomsuksa 1 to 6 (equivalent to elementary level grade 1 to 6) and Matthayom 1 to 6 (equivalent to secondary level grade 7 to 12 ).

3. This is similar to what Pat Thomson (2017) calls the 'laundry list' literature review.

4. Around $93 \%$ of Thai people practice Buddhism (National Statistical Office of Thailand \& Ministry of Information and Communications Technology, 2016).

\section{Acknowledgements}

We would like to express our gratitude to our colleagues Titikarn Assatarakul, Katerut Laothamatas and Suthiporn Sajjapanroj who taught alongside us in this course.

\section{References}

Bansel, P. (2011). Becoming academic: A reflection on doctoral candidacy. Studies in Higher Education, 36(5), 543-556. doi: 10.1080/03075079.2011.594592

Barbezat, D. \& Bush, M. (2014). Contemplative practices in Higher Education: Powerful methods to transform teaching and learning. San Francisco, CA: Jossey-Bass.

Blackmore, J. (2009). Academic pedagogies, quality logics and performative universities: Evaluating teaching and what students want. Studies in Higher Education, 34(8), 857-872. doi: $\underline{10.1080 / 03075070902898664}$

Borker, D. (2013). Mindfulness practices for accounting and business education: A new perspective. American Journal of Business Education, 6(1), 41-56.

Bromley, P. (2017). Locating Canadian writing centres: An empirical investigation. Canadian Journal for Studies in Discourse and Writing/Rédactologie, 27, 24-41.

Bryant, K. N. (2012). "Free your mind... and the rest will follow": A secularly contemplative approach to teaching high school English. Unpublished doctoral dissertation. University of South Florida. Retrieved from http://scholarcommons.usf.edu/etd/3996

Bureau of Academic Affairs and Educational Standards (2001). Basic Education Curriculum. Retrieved from http://academic.obec.go.th/web/home

Burford, J. (2015). Queerying the affective politics of doctoral education: Toward complex visions of agency and affect. Higher Education Research \& Development, 34(4), 776-787. doi: 
Volume 28, 2018

http://journals.sfu.ca/cjsdw

Burford, J. (2017a). Conceptualising doctoral writing as an affective-political practice. International Journal of Doctoral Studies, 12, 17-32. doi: 10.28945/3689

Burford, J. (2017b). Not writing, and giving zero-f**ks about it: Queer(y)ing doctoral 'failure'. Discourse: Studies in the Cultural Politics of Education, 38(4), 473-484. doi: $\underline{10.1080 / 01596306.2015 .1105788}$

Burton, V. (2016, June 2). Mindfulness for distracted writers [Blog post]. Retrieved from http://blogs.oregonstate.edu/wicnews/2016/06/02/mindfulness-distracted-writers/

Chaisiri, T. (2011). Teaching writing in a Thai university context: Considerations for introducing a genre-based approach (Unpublished doctoral dissertation). University of South Australia, Australia.

Cribb, A., \& Gewirtz, S. (2006). Doctoral student supervision in a managerial climate. Sociology of Education, 16(3), 223-236. doi: 10.1080/09620210601037787

Cuthbert, D. \& Spark, C. (2008). Getting a GRiP: Examining the outcomes of a pilot program to support graduate research students in writing for publication. Studies in Higher Education, 33(1), 77-88. doi: 10.1080/03075070701794841

Davis, J. (2004). The journey from the center to the page: Yoga philosophies and practices as a muse for authentic writing. New York, NY: Gotham Books.

Goldberg, N. (1986). Writing down the bones: Freeing the writer within. Boston, MA: Shambala Press.

Grace, F. (2011). Learning as a path, not a goal: Contemplative pedagogy—its principles and practices. Teaching Theology \& Religion, 12(2), 99-124. doi: 10.1111/j.1467-9647.2011.00689.x

Haggis, T. (2006). Pedagogies for diversity: Retaining critical challenge amidst fears of 'dumbing down'. Studies in Higher Education, 31(5), 521-535. doi: 10.1080/03075070600922709

Jones, L. (2016). Noticing deeply through contemplative writing. In J. Buley, D. Buley \& R. Collister (Eds.), The Art of Noticing Deeply: Commentaries on teaching, learning and mindfulness (pp. 6777). Newcastle upon Tyne, England: Cambridge Scholars Publishing.

Killen, P. O., \& De Beer, J. (1994). The art of theological reflection. New York, NY: Crossroads. Lamott, A. (1995). Bird by bird: Some instructions on writing and life. New York, NY: Anchor Books. Lao, R. (2015). A critical study of Thailand's higher education reform: The culture of borrowing. Oxon: Routledge.

Lee, A., \& Boud, D. (2009). Framing doctoral education as a practice. In D. Boud \& A. Lee (Eds.), Changing practices of doctoral education (pp. 10-25). Abingdon, UK: Routledge. 
Volume 28, 2018

http://journals.sfu.ca/cjsdw

Lee, A., \& Aitchison, C. (2009). Writing for the doctorate and beyond. In D. Boud \& A. Lee (Eds.), Changing practices of doctoral education (pp. 87-99). Abingdon, UK: Routledge.

Li, Y. (2015). "Publish SCI papers or no degree": Practices of Chinese doctoral supervisors in response to the publication pressure on science students. Asia Pacific Journal of Education. doi: $\underline{10.1080 / 02188791.2015 .1005050}$

Lillis, T. \& Scott, M. (2007). Defining academic literacies research: Issues of epistemology, ideology and strategy. Journal of Applied Linguistics, 4(1), 5-32. doi: 10.1558/japl.v4i1.5

Meekun, K. (2009). Literature review [PDF document]. Retrieved from http://rlc.nrct.go.th/ewtadmin/ewt/nrct museum/ewt dl.php?nid=710

Miller, S. (1991). Textual carnivals: Politics of composition. Carbondale, IL: Southern Illinois University Press.

Miller, M. \& Bhattacharya, K. (2017). Call for papers, Across the Disciplines, Special issue: Teaching contemplative writing across the disciplines. Retrieved from https://wac.colostate.edu/atd/call contemplative writ acr discip.cfm

Morgan, P. (2012). Following contemplative education students' transformation through their "ground-of-being" experiences. Journal of Transformative Education, 10(1), 42-60. doi: $\underline{10.1177 / 1541344612455846}$

Morgan, P. (2015). A brief history of the current reemergence of contemplative education. Journal of Transformative Education, 13(3), 197-218. doi: 10.1177/1541344614564875

NCTE - National Council of Teachers of English, (2017). Standing groups. Retrieved from http://www.ncte.org/library/NCTEFiles/Groups/CCCC/2017CCCCSIGs_StandingGroups.pdf

Nuangchalerm, P. \& Prachagool, V. (2010). Promoting transformative learning of preservice teacher through contemplative practices. Asian Social Science, 6(1), 95-99. http://dx.doi.org/10.5539/ass.v6n1p95

Nilchaikovit, T. \& Juntrasook, A. (2016). The arts of transformative learning facilitation: A contemplative approach (2nd Ed.). Leadership for the Future Project: Nakorn Pathom.

O’Reilley, M. (1998). Radical Presence. Portsmouth, NH: Boynton/Cook Publishers.

Paré, A. (2017). The once and future writing centre: A reflection and critique. Canadian Journal for Studies in Discourse and Writing/Rédactologie, 27, p. 1-12.

Phuangpornpitak, N. (n.d.). Techniques for doing literature review and developing research framework [PDF document]. Retrieved from http://nrctne.kku.ac.th/images/uploads/news/bf3aaadf8831064c00aadc69ad4b302cdab2c399.pdf 
Volume 28, 2018

http://journals.sfu.ca/cjsdw

Reynolds, N. (2004). Geographies of writing: Inhabiting places and encountering difference.

Carbondale, IL: Southern Illinois University Press.

Shapiro, S., Brown, K. \& Astin, J. (2011). Toward the integration of meditation into higher education: A review of research evidence. Teachers College Record, 113(3), 493-528.

Simmer-Brown, J. (2016). Words and sense: Contemplative pedagogies in academic writing. The Journal of Contemplative Inquiry, 3(1), 97-111.

Sorapat, U. (2014). Students' and instructors' perceptions of students' difficulties in writing academic assignments. Panyapiwat, 6(1), 115-132.

Suriya, K. (n.d.). Research tips part 2: Literature review writing. Retrieved from http://hq.prd.go.th/plan/ewt_dl_link.php?nid=2104

Sword, H. (2017). Air \& light \& time \& space: How successful academic writers write. Cambridge, MA: Harvard University Press.

Tangkiengsirisin, S. (2011). Effectiveness of student responses to teacher written feedback: A study of Thai graduate students. Journal of English Studies, 6, 162-184.

Teerakul, N. (n.d.). Literature review [PDF document]. Retrieved from http://fuangfah.econ.cmu.ac.th/files/751408 part\%202 sem2 2556 Nuttamon.pdf

Tennant, M., McMullen, C., \& Kaczynski, D. (Eds.). (2010). Teaching, learning and research in higher education: A critical approach. New York: Routledge.

Thaotrakool, N. (2016). Literature review [PDF document]. Retrieved from http://research.bsru.ac.th/spare2/doc/25-29/G4/26-April-59.pdf

Thomson, P. (2017, September 11). Avoiding the laundry list literature review. Patter. Retrieved from https://patthomson.net/2017/09/11/avoiding-the-laundry-list-literature-review/

Vasi, P. (2007). Universities and contemplative education: The triangle of education. Bangkok: Contemplative Education Centre Mahidol University.

Wellington, J., Bathmaker, A., Hunt, C., McCulloch, G., \& Sikes, P. (Eds.). (2005). Succeeding with your doctorate. London, UK: Sage Publications.

Wenger, C. (2015). Yoga minds, writing bodies: Contemplative writing pedagogy, Anderson, SC: Parlour Press.

White, J. (2015). Shaping PhD researchers: Fearless intellectuals or managed employees. The Malaysian Journal of Qualitative Research, 11(1), 1-17.

Zajonc, A. (2013). Contemplative pedagogy: A quiet revolution in higher education. New Directions in Teaching and Learning, 134, 83-94. doi: 10.1002/tl.20057 